\title{
Implementasi Sistem Layanan Informasi Profil Desa Melalui Media Online Untuk Meningkatkan Tranparansi Informasi Desa
}

\author{
Mansur \\ Teknik Informatika \\ Politeknik Negeri Bengkalis \\ J1. Bathin Alam, Sungai Alam, Bengkalis, Riau, Indonesia \\ mansur.polbeng82@gmail.com
}

\begin{abstract}
ABSTRAK
Sistem layanan informasi profil desa memiliki peranan penting dalam membantu perangkat desa untuk mengumpulkan data dan menyajikan informasi secara luas kepada masyarakat sehingga pengembangan desa dapat diketahui oleh masyarakat secara up-to-date, bahkan akan memungkinkan terjalinnya kerjasama desa dengan pihak lain yang bermanfaat bagi desa tersebut. Dalam hal ini, masyarakat juga berperan aktif untuk membantu mendorong perkembangan pemerintah desa dengan memberikan masukan kepada perangkat desa. Untuk itu, perlu dilakukan implementasi sistem layanan informasi profil desa melalui media online untuk meningkatkan tranparansi informasi desa dengan menggunakan bahasa pemograman PHP dan MySQL sebagai database. Implementasi sistem tersebut dapat membantu perangkat desa dalam mengumpulkan data, dokumentasi kegiatan dan menyajikan informasi seperti informasi profile desa meliputi sambutan, sejarah, struktur organisasi, perangkat desa dan visi misi desa, informasi mengenai kelembagaan meliputi pemberdayaan masyarakat, lembaga adat, PKK, BUMDES, karang taruna dan lembaga lain, informasi monografi meliputi data umum, kependudukan, sarana dan prasarana, kewenangan, keuangan dan data bencana, dan informasi direktori meliputi peraturan, berita, daftar kegiatan, potensi, galeri dan buku tamu serta informasi monografi dalam bentuk grafik yang disampaikan kepada masyarakat secara cepat sehingga dapat dijadikan sebagai wadah untuk mempromosikan potensi desa kepada masyarakat luar secara luas.
\end{abstract}

Keywords : Sistem Implementatsi, Layanan informasi, media online, Profil Desa,

\begin{abstract}
Village profile information service system has an important role in helping the village to collect data and provide information to the wider community so that the development of the village can be known by the community up-todate, even it will allow the establishment of cooperation with other parties that are beneficial to the village, in this case, the public also play an active role to help driven the development of the village government to provide feedback to the village. Therefore, need to be done implementation of Village profile information service system through online media to increase transparency village information using the programming language PHP and $M y S Q L$ as database. Implementation of the system can help the village to collect data, documentation of activities and presents information such as profile information includes the village of welcoming, history, organizational structure, village councilor, and mission vision of the village, Includes information on the institutional empowerment, customs agency, the PKK, BUMDES, youth organization, and other institutions, monograph information includes general data, population, infrastructure, authority, financial and disaster data, and directory information include regulations, news, a list of activities, potential, gallery and guest book as well as a monograph information in graphic form submitted to the public quickly so that it can serve as a forum to promote the potential of the village to the outside of community widely.
\end{abstract}

Keywords : Implementation system, information service, online media, village profile 


\section{Pendahuluan}

Perkembangan sistem layanan informasi sudah menguasai banyak bidang baik perusahaan, pemerintah pusat, daerah maupun dikalangan pemerintah desa. Saat ini, pemerintah Kabupaten Bengkalis sudah mendorong kepada desa untuk memiliki layanan informasi melalui website desa, untuk mewujudkan pemerintah desa yang transparan sehingga masyarakat dapat berperan aktif sebagai pengawas ekternal dalam memantau kegiatan dan perkembangan yang dilakukan oleh desa. Meskipun sejauh ini belum seluruh desa di Kabupaten Bengkalis memiliki website, namun bagi desa yang sudah memiliki akses jaringan internet menjadi suatu kewajiban untuk memiliki website sebagai sarana berbagi informasi kepada masyarakat. Selain itu, keberadaan website desa juga dapat dimanfaatkan untuk mempromosikan potensi yang dimiliki oleh desa tersebut lewat website desa secara luas [4].

Untuk menghasilkan informasi yang baik dan efektif sistem harus mampu memberikan kontribusi kepada pengguna dan memberikan manfaat kepada organisasi sehingga memberikan dampak terhadap performance sistem dalam meningkatkan kualitas informasi yang efektif dengan menampilkan informasi yang up-todate, sederhana dan menarik perhatian pengguna [6]. Untuk itu, perlu implementasi sistem yang merupakan suatu proses penerapan dalam rangka menempatkan sistem baru kedalam sistem yang sudah ada atau belum ada sesuai dengan kesepakatan organisasi dengan memperhatikan kepuasan pengguna dan efektivitas sistem yang berdampak pada organisasi [7]. Selain itu, implementasi sistem merupakan tahapan akhir dalam pengembangan sistem yang dilakukan dan diuji sesuai kebutuhan pengguna sistem [8].

Dalam melakukan proses pengembangan dan implementasi sistem informasi hampir $40 \%$ proyek tersebut terjadi kegagalan dan tidak sesuai dengan pengguna akhir. Ada beberapa klasifikasi yang ditemukan oleh grop Standish untuk menentukan keberhasilan dalam merealisasi pengembangan sistem yaitu proyek suskses, proyek gagal, dan proyek melebihi rentang waktu yang ditetapkan (Ciric dan Rakovic, 2010). Untuk mengatasi hal itu, perlu fokus dalam melakukan proses implementasi sistem sehingga proyek dapat berjalan dengan baik (Hyotylainen, 2013).

Berdasarkan permasalahan diatas peneliti tertarik untuk melakukan implementasi sistem layanan informasi profil desa melalui media online untuk meningkatkan tranparansi informasi desa. Dengan adanya layanan tersebut dapat membantu pemerintah desa dalam menyajikan dan menyebarluaskan informasi desa secara luas kepada masyarakat, serta menjadikan wadah untuk dapat mempromosikan potensi desa kepada masyarakat luar melalui media online secara luas.

\section{Krangka Teori}

\subsection{Layanan informasi melalui media online}

Media Website merupakan salah satu upaya yang dilakukan oleh perusahaan/ organisasi/ pemerintah dalam mendorong percepatan reformasi informasi untuk memperbaiki citra layanan publik sehingga mampu meningkatkan kualitas pelayanan bagi masyarakat. Pengelolaan media online secara optimal akan membantu perusahaan/organisasi/ pemerintah dalam menyajikan data dan informasi kepada masyarakat secara luas, cepat dan dapat menghemat waktu tanpa harus mengunjungi daerah tersebut. Ada beberapa mekanisme dalam pelayanan informasi yaitu 1) Informasi Publik yang tersedia dan diumumkan secara berkala, 2) permintaan informasi yang disediakan setiap saat, permintaan ini biasanya berdasarkan permintaan secara tertulis, tidak tertulis, dan pendokumentasian permintaan informasi baik secara tertulis maupun tidak tertulis. Optimalisasi pengelolaan tersebut juga berdampak kepada pengetahuan masyarakat umum tentang potensi daerah yang dimiliki oleh masing-masing pemerintah terutama desa. Untuk mengoptimalkan layanan informasi perlu melakukan proses pengklasifikasikan informasi, informasi dapat dikelompokkan menjadi dua yaitu [4]:

1. Informasi yang bersifat publik, merupakan informasi yang didapatkan dari tugas pokok, fungsi dan kegiatan setiap satuan kerja.

2. Informasi yang dikecualikan dapat dikelompokan menjadi tiga yaitu 1) informasi ketat artinya informasi yang dikecualikan harus benar-benar mengacu pada metode yang valid dan mengedepankan obyektivitas, 2) terbatas artinya informasi yang dikecualikan harus terbatas pada informasi tertentu untuk menghindari penafsiran yang subyektif, dan 3) tidak mutlak artinya tidak ada informasi yang secara mutlak dikecualikan ketika kepentingan publik yang lebih besar menghendakinya.

Pengelompokan informasi merupakan tahapan dalam melakukan kegiatan pengumpulan data yang merupakan tahapan penting dalam pengelolaan informasi dan dokumentasi dengan memperhatikan beberapa hal sebagai berikut [4] :

1. Pengumpulan informasi merupakan aktivitas penghimpunan kegiatan yang telah, sedang dan yang akan dilaksanakan oleh setiap satuan kerja.

2. Informasi yang dikumpulkan adalah informasi yang berkualitas dan relevan dengan tugas pokok dan fungsi masing-masing satuan kerja.

3. Informasi yang dikumpulkan dapat bersumber dari pejabat dan arsip. 
4. Peyediaan informasi dilaksanakan dengan memperhatikan tugas pokok dan fungsi satuan kerja, mendata kegiatan satuan kerja, mendata informasi dan dokumen yang dihasilkan serta membuat daftar jenis informasi dan dokumen.

Selain itu, akses layanan informasi desa sangat untuk dilakukan pengembangan sebab hal tersebut berhubung dengan potensi desa sendiri sehingga masyarakat desa baik dalam maupun luar dapat mengakses informasi tersebut dengan baik dan cepat bahkan akan memungkinkan terjalinnya kerjasama desa dengan pihak lain yang bermanfaat bagi desa tersebut. Beberapa factor yang menjadi perhatian pemerintah dalam hal profil desa yaitu 1) profil desa tidak cukup memadai sebagai instrument dan ruang akuntabilitas publik yang menjadi modal bagi demokrasi desa, 2) profil desa secara teknis kurang memadai sebab yang dapat menginput data tersebut hanya perangkat desa. Hal ini, akan berhasil dengan adanya dukungan masyarakat, tanpa keikutsertaan masyarakat maka sistem informasi desa hanya menjadi sistem perangkat aparat desa yang kurang bermakna bagi masyarakat luas [5].

\subsection{Implementasi sistem}

Menurut Thong (2001), implementasi sistem pada perusahaan besar dibandingkan dengan perusahan/organisasi kecil sangatlah berbeda. Hal tersebut, disebabkan factor sumber daya manusia dan biaya. Ada beberapa factor yang menjadi kendala dalam implementasi sistem yaitu kepuasan pengguna sistem dan efektivitas sistem yang berdampak pada organisasi. Untuk mekanisme pengembangan dari proses implementasi sistem informasi terdiri dari empat kegiatan yaitu 1) defining the innovation problem and goal setting; 2) planning activity; 3) implementation activity; and 4) use and development activity [2]. Untuk lebih jelas dapat dilihat pada gambar 1 .

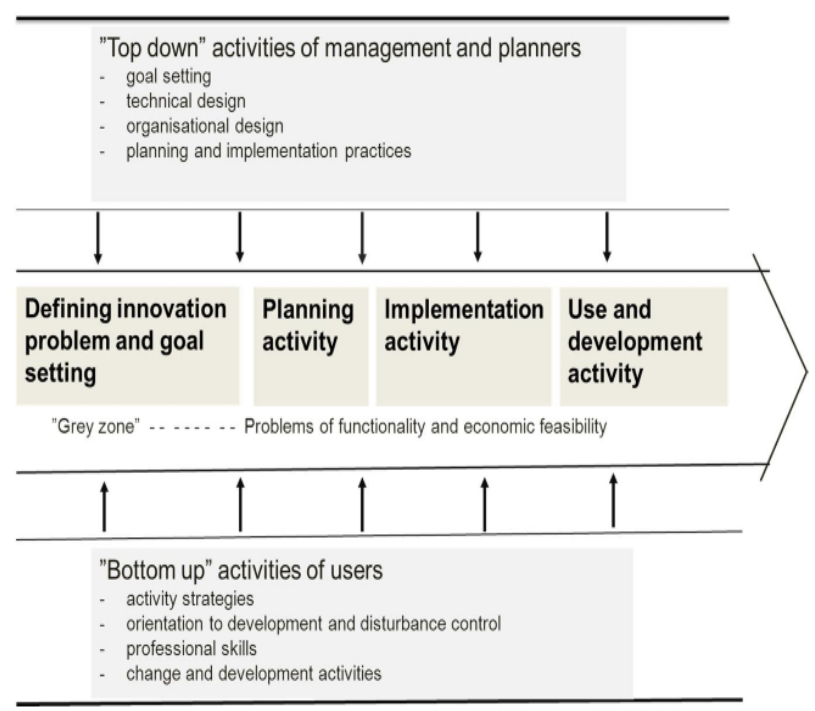

Gambar 1. Model perencanaan dan implementasi sistem informasi.

\section{Metode}

\subsection{Prosedur peneltian}

Adapun langkah-langkah yang dilakukan dalam prosedur penelitian ini dimulai dengan melakukan identifikasi masalah dilapangan, mendapatkan data yang dibutuhkan, menganalisa kebutuhan sistem, merancang dan membuat, melakukan pengujian serta mengimplementasikan layanan informasi desa kepada perangkat desa. Langkah-langkah ini dibuat agar penelitian ini lebih terarah dan dapat dilihat pada Gambar 2.

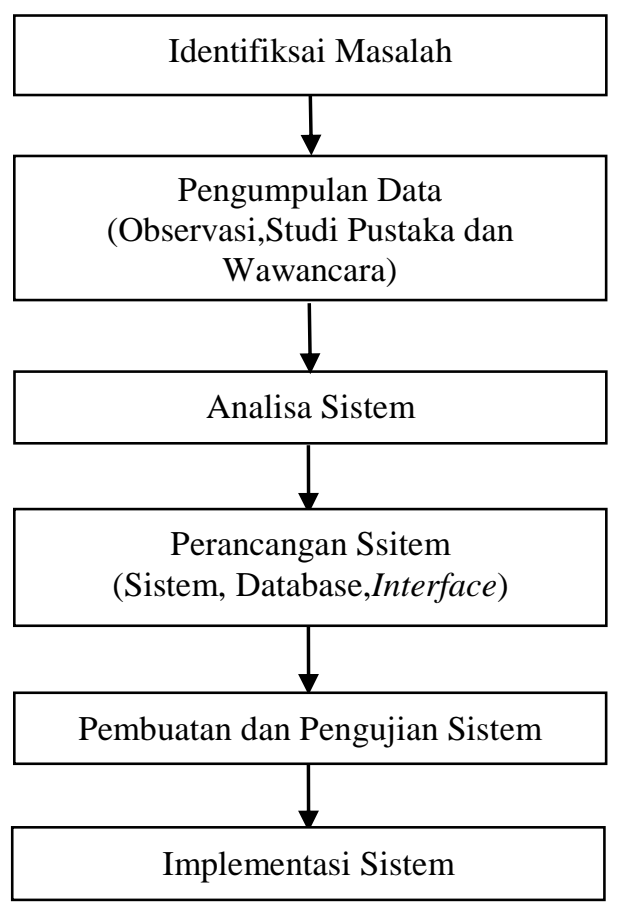

Gambar 2. Prosedur Penelitian 


\subsection{Perancangan Sistem}

Perancangan sistem yang dibuat agar dapat mengetahui alur kerja sistem yang terjadi sehingga dapat mengambarkan rancangan sistem yang di implementasikan.

\subsubsection{Use Case Diagram}

Use case diagram untuk layanan informasi profil desa melibatkan dua aktor yaitu operator desa dan masyarakat sebagai pengunjung. Operator desa berfungsi untuk mengelola halaman web mulai dari mendaftarkan profil desa, input data, update data, hapus data, dan validasi buku tamu yang diisi oleh pengunjung. Sedangkan aktor pengungjung berfungsi untuk melihat informasi dan memberikan masukan melalui kepada perangkat desa melalui buku tamu serta mengisi poling yang tersedia. Untuk lebih jelas dapat dilihat pada Gambar 3.

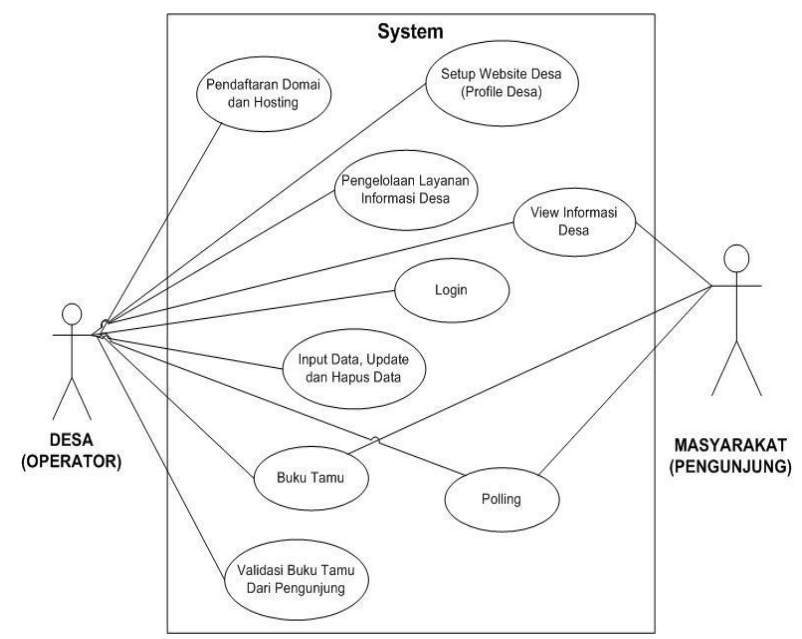

Gambar 3. Use case diagram untuk layanan informasi desa.

\section{Hasil dan Pembahasan}

Hasil penelitian ini berupa sebuah website profil desa yang dapat membantu perangkat desa dalam menyajikan dan menyebarluaskan informasi secara luas kepada masyarakat. Layanan tersebut dapat menyampaikan informasi seperti sambutan, sejarah, struktur organisasi, perangkat desa dan visi misi desa, informasi mengenai kelembagaan meliputi pemberdayaan masyarakat, lembaga adat, PKK, Bumdes, karang taruna dan lembaga lain, informasi monografi meliputi data umum, kependudukan, sarana dan prasarana, kewenangan, keuangan dan data bencana, dan informasi direktori meliputi peraturan, berita, daftar kegiatan, potensi, galeri dan buku tamu, serta dapat melihat informasi dalam bentuk grafik.

\section{Hasil Implementasi Layanan Informasi Desa}

Copyright (C) 2017 FIKOM - UNASMAN

http://ejournal.fikom-unasman.ac.id
Implementasi layanan informasi profil desa melalui media online dilakukan pada desa sungai alam dan desa meskom Kecamatan Bengkalis Kabupaten Bengkalis. Layanan informasi tersebut dapat digunakan lebih dari satu desa sebagai media online untuk menyampaikan informasi serta promosi desa kepada masyarakat desa baik skala daerah dan nasional. Untuk lebih jelas dapat dilihat pada bagian dibawah ini.

1. Gambar 4 dan 5, menjelaskan tentang halaman utama dari layanan informasi desa sungai alam dan desa meskom yang berisi beberapa menu seperti home, profil, kelembagaan, monografi dan direktori desa.

2. Gambar 6, menjelaskan tentang informasi perangkat setiap desa mulai dari data kepala desa sampai dengan anggota.

3. Gambar 7, menjelaskan bagian dari monografi desa mulai dari data umum, kependudukan, sarana dan prasarana, kewenangan, keuangan dan tatatertib desa.

4. Gambar 8, menjelaskan tentang grafik kependudukan berdasarkan jenis kelamin, usia, pendidikan umum dan pendidikan khusus.

5. Gambar 9, menjelaskan tentang daftar kegiatan yang dilakukan oleh setiap desa.

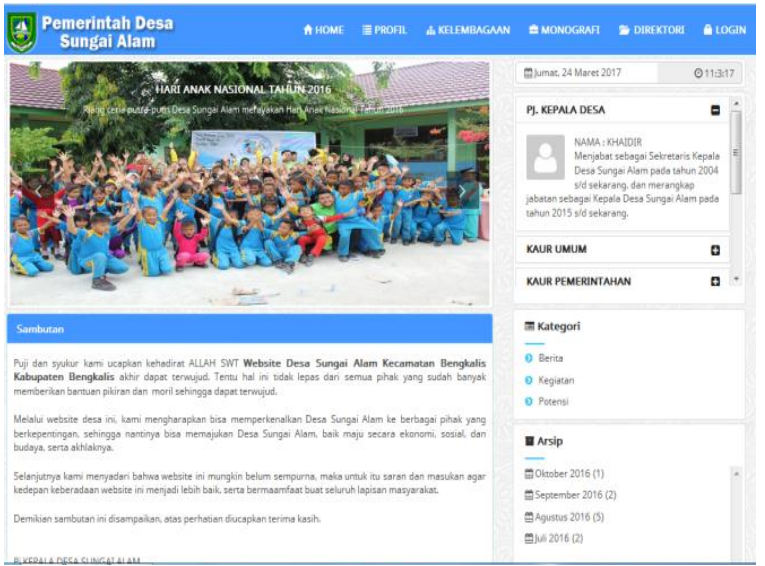

Gambar 4. Layanan Informasi Desa Sungai Alam

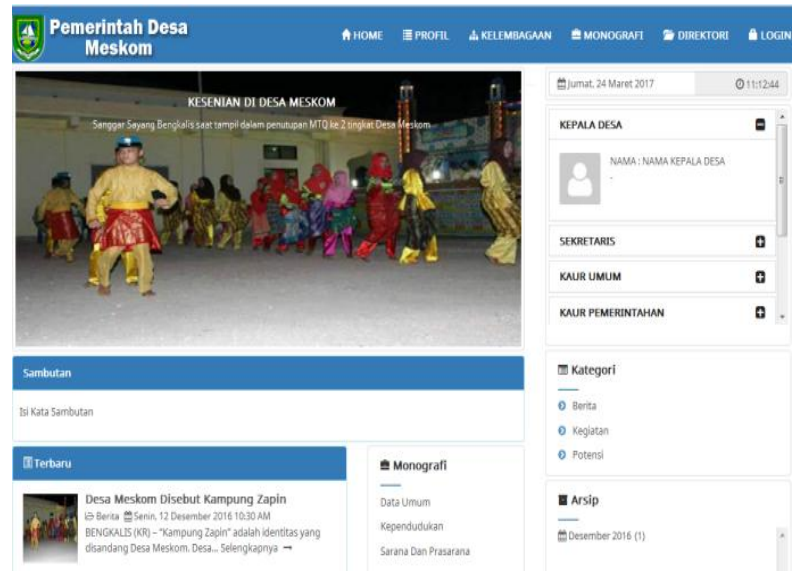


Gambar 5. Layanan Informasi Desa Meskom

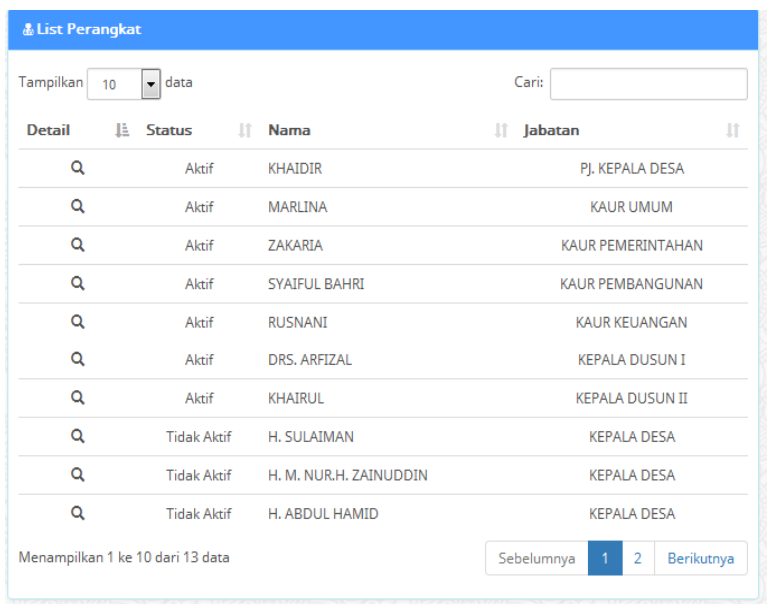

Gambar 6. Informasi Perangkat Desa

\section{EMonografi | Umum}

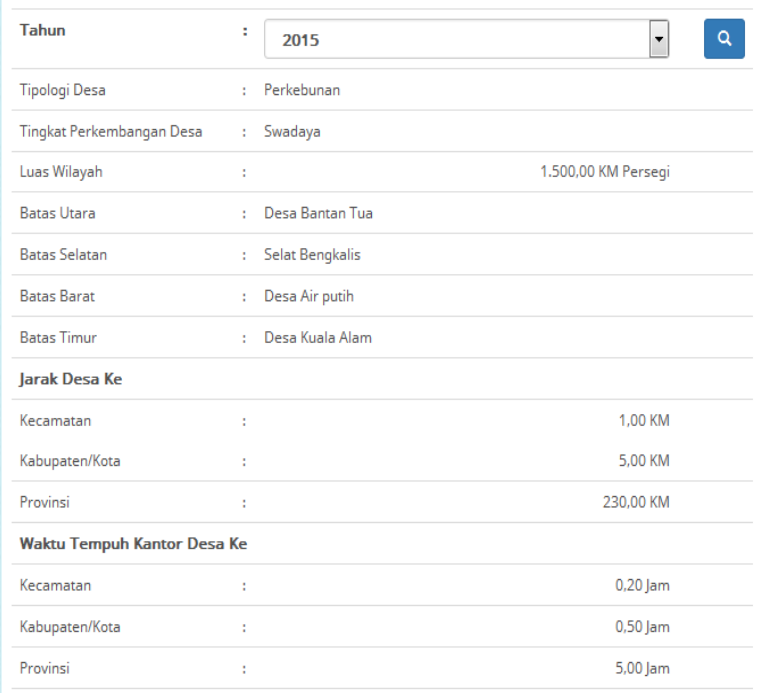

Gambar 7. Monografi Profil Desa

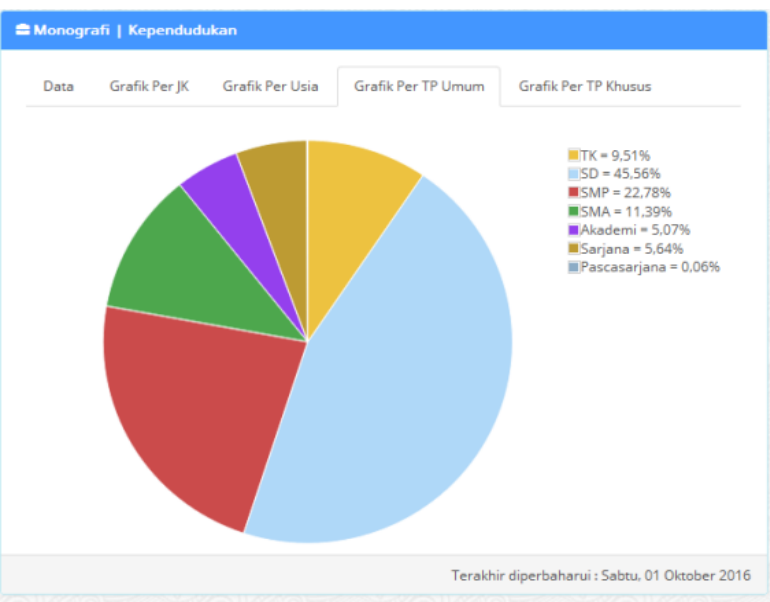

Gambar 8. Grafik Kependudukan Berdasarkan Tingkat Pendidikan Umum

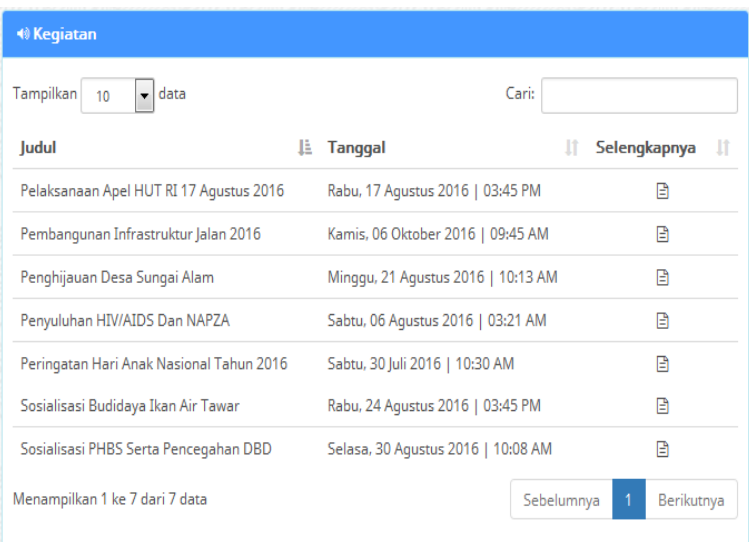

Gambar 9. Daftar Kegiatan Desa

\section{Pembahasan}

Implementasi layanan informasi profil desa melalui media online untuk meningkatkan tranparansi informasi desa dilakukan pada dua desa yaitu desa sungai alam (http://sungaialam.desa.id/) dan desa meskom (http://meskom.desa.id/) di Kabupaten Bengkalis. Dalam melaksanakan implementasi sistem tersebut dapat dipastikan bahwa mulai dari konfigurasi sistem sampai dengan star-up sistem berjalan dengan baik. Pengujian sistem dilakukan pada proses input dan output. Berikut hasil pengujian proses input dab output sistem, hal tersebut dapat dilihat pada tabel 3.2.

Tabel 3.2 Hasil Pengujian Input Output

\begin{tabular}{l|l|c|c}
\hline \multirow{2}{*}{ NO } & \multirow{2}{*}{ Item pengujian input } & \multicolumn{2}{|c}{ Hasil } \\
\cline { 2 - 4 } A & Proses Input Data & Berhasil & Gagal \\
\hline 1 & Login operator desa & $\checkmark$ & - \\
\hline 2 & Input menu profil & $\checkmark$ & - \\
\hline 3 & Input menu kelembagaan & $\checkmark$ & - \\
\hline 4 & Input menu monografi & $\checkmark$ & - \\
\hline 5 & Input menu direktori & $\checkmark$ & - \\
\hline B & Proses Output Data penduduk & $\checkmark$ & - \\
\hline 1 & $\begin{array}{l}\text { Grafik jenis } \\
\text { berdasarkan penduduk } \\
\text { kelamin }\end{array}$ & $\checkmark$ & \\
\hline 2 & $\begin{array}{l}\text { Grafik penduduk } \\
\text { berdasarkan usia }\end{array}$ & $\checkmark$ & - \\
\hline 3 & $\begin{array}{l}\text { Grafik tingkat } \\
\text { berdasarkan tingkat } \\
\text { pendidikan umum }\end{array}$ & & \\
\hline 4 & $\begin{array}{l}\text { Grafik } \\
\text { berdasarkan penduduk } \\
\text { pendidikan khusus }\end{array}$ & $\checkmark$ & - \\
\hline 5 & Daftar kegiatan desa & $\checkmark$ & - \\
\hline
\end{tabular}




\section{Kesimpulan}

Implementasi layanan informasi profil desa melalui media online untuk meningkatkan tranparansi informasi desa dapat membantu pemerintah daerah yaitu desa dalam hal pengelolaan data, informasi dan penyajian informasi secara luas kepada masyarakat yang merupakan pengguna utama informasi desa. Penyediaan layanan informasi tersebut berupa informasi profile desa seperti sambutan, sejarah, struktur organisasi, desa, visi misi, informasi mengenai kelembagaan (pemberdayaan masyarakat, lembaga adat, PKK, Bumdes, dan karang taruna), informasi monografi (data umum, kependudukan, sarana prasarana, kewenangan, perangkat keuangan dan data bencana), informasi peraturan, berita, daftar kegiatan, potensi, galeri, buku tamu, dan informasi dalam bentuk grafik kepada masyarakat secara luas dalam rangka mewujudkan pemerintah desa yang transparan serta dapat mempromosikan potensi desa kepada masyarakat luas.

\section{Daftar Pustaka}

[1] Ciric, Z., dan Rakovic, L., (2010), Change Management in Information System Development and Implementation Projects, Management Information Systems, Vol. 5, pp. 023-028.

[2] Hyotylainen, R., (2013), Implementation of Information System as an Organisational Construction, ISSN-L 2242-119X, ISSN 2242-119X (Print), ISSN 22421203 (Online)

[3] Kasmawi dan Mansur, 2016, Analisa dan Desain Sistem untuk Layanan Informasi Website Desa, SNIT 2016, ISSN : 2303-2790

[4] Kepmen Kominfo Nomor 117 Tahun (2010), Tentang Organisasi Pengelolaan Informasi dan Dokumentasi Kementerian Komunikasi dan Informatika. Jakarta.

[5] Sulistyowati, F., dan Dibyorin, C.R., 2013, Partisipasi warga terhadap sistem informasi desa, Jurnal Komunikasi ASPOKOM, Volume 2, Nomor 1, hlm. 579-587.

[6] Thong, L.Y,J., dan Yap, S.C,. (1996), Information System Effectiviness : A User Statisfaction Approach, informaticm Processing \& Management, Vol. 32, No. 5, pp. 601-610.

[7] Thong, J.Y.L., (2001), Resource Constraints and Information Systems Implementation in Singaporean Small Businesses, Omega The International Journal of Management Science, 0305-0483/01/\$ - PII: S0305-0483(00) 00035-9.

[8] Valacich, J.S., George, J.F., dan Hoffer, J.A, (2012), Essensial of Systems Analysis and Design, Prentice Hall, New Jersey. 